\title{
Kaingang: gender or classifiers?
}

\author{
Wilmar da Rocha D’Angelis ${ }^{1}$
}

Le genre grammatical est l'une des categories grammaticales les moins logiques et le plus innattendue.

(A. Meillet 1965:202) ${ }^{2}$

The linguistic system, yet stripped from "reason" (or by force be stripped from reason) always speaks to imagination and drives it.

(L. Hjemslev 1971:227)

\begin{abstract}
The Kaingang language presents a particular vocalic alternation involving low nasal vowels, which has traditionally been treated either as dialect differences or as a case of "free variation". My two-decade contact with native speakers of several Kaingang communities - particularly from Xapecó (SC), Nonoai, and Inhacorá (RS) - allows me to consider this vocalic alternation as a kind of "classifier" with some characteristics of "gender". This paper argues that these distinctions in pronunciation are not mere dialect differences in Kaingang. The linguistic reality is much richer, more revealing and more interesting than the magical discard of "free variation".
\end{abstract}

\section{Introduction}

The Kaingang language presents a particular vocalic alternation involving low nasal vowels, which has traditionally been treated either as dialect

\footnotetext{
1 Doctor in Linguistics and indigenist, Professor at the Linguistics Department of Unicamp (Campinas, SOP - Brazil)

2 "Grammatical gender is one of the least logical and more unexpected grammatical categories".
} 
differences or as a case of "free variation". Briefly, on a wide set of names (but also some verbs), a pronunciation alternation is possible, and where it operates it seems desirable, using the half-open anterior nasal vowel $|\tilde{\varepsilon}|$ when one represents a circumstance which associates the term to the qualifiers "tall/long" or "thin/diffuse", and using the back half-open nasal vowel $|\tilde{\jmath}|$ when, for the same term, one introduces a circumstance which associates to the qualifiers "short/round" or "thick/compact". In other words, it is not an exclusively semantic component, which would point to classifiers, it also involves a morphophonological alternation, which is similar to a gender marking in its semantic-pragmatic feature, that allows to distinguish, for example, "full moon" from "waning moon", and a "big eye" from a "small eye".

The opposition ror $\mathrm{x}$ tej (short/round $\mathrm{x}$ tall/long) is very important as a classificatory category for the Kaingang cosmovision, associated to the patrilineal exogamous moieties Kanhru and Kamẽ, respectively (cf. VEIGA, 1994). Animals, plants and people (these, by their ascendancy and also by their names) are classified in one of these categories. Could the vocalic alternation in question be an amplification - or grammaticalization - of that classificatory system? Another linguistic fact would corroborate the hypothesis: the existence of specific verb forms selected to co-occur, according to the situation, with "round" or "long" objects.

Possibly, nowadays, due to the pressure of bilingualism, this particular feature of Kaingang no longer survives in some (or several) of the communities that speak that language. This paper argues, however, that the pronunciation distinctions, such as $\left.\left|k e^{\prime} \int \tilde{\varepsilon}\right| x \mid k e ́\right\} \int \tilde{\jmath} \mid$, are not mere dialect differences in Kaingang. The linguistic reality is much richer, more revealing and more interesting than the magical discard of "free variation". ${ }^{3}$

\section{The Interpretation of a Linguistic Question, According to the Speakers}

When I started to live with the Kaingang, as an indigenist, on the West of Santa Catarina and on the North of Rio Grande do Sul, I was interested in their language, but there were several other urgent tasks, such as the fight for land, the search for economic alternatives, and so many others. All these imperative issues forced us to use Portuguese in our interactions. In spite of that, I kept my interest in learning the language. As a reader of Wiesemann (1967), I learned that the variation in the use of nasal vowels $|\tilde{\varepsilon}|$ and $|\tilde{\jmath}|$ was due to dialect distinction. So, not being a linguist myself in that time, and

3 This paper was originally published in Portuguese, under the title "Gênero em Kaingang?" in the compilation "Línguas Jê: estudos vários" organized by Ludoviko dos Santos and Ismael Pontes (Londrina: Eduel, 2002). 
not having the necessary conditions to carry on a proper systematic study, I assumed that that information was correct. However, my ears insisted in hearing pronunciations that did not fit the scheme. As those were not my main concerns, I discarded the problem with hypothesis about several origins of the people of the village, or the parents of the people I knew.

When linguistics became more than a pastime, I started to think about that problem again, although I did not try to organize the facts. So, at the beginning of the 90's, I asked Vicente Fókáe, an old Kaingang indian who had been my first teacher of his language, why was there a difference on the pronunciation of certain words, which I sometimes heard with $|\tilde{\varepsilon}|$ and sometimes with $|\tilde{\mid}|$. The answer surprised me but did not clarify the matter at that moment: "One is thinner, the other is thicker. It's female and male."

My knowledge of the language, yet restricted, allowed me to know that "female" and "male" referring to sex, in Kaingang language, obeyed a different marking resource. ${ }^{4}$ At the same time, this knowledge gave me the conviction that it didn't refer to "masculine" and "feminine" talk, because I had heard the same man or woman, one time or another, pronouncing the same word in a different way from that I had heard before, and I had also heard both men and women pronouncing the same words on identical ways, in other occasions. I kept the Vicente's words in mind, but I did not carry on the investigation.

An excellent opportunity to resume the question came up when I was working as adviser to the Kaingáng Indian school in Inhacorá (RS). As I was coordinating the development of specific teaching materials for the literacy project in Kaingáng, we had to selecti generative-words (/themes) in Kaingang and produce an illustrated banner for each of the themes.

Several linguistic discussions took place, with the Kaingáng teachers of the community and that was (and still is) for me one of the best experiences a linguist can have. Some of those discussions concerned writing, given the quite general dissatisfaction with the "official" orthography of Kaingang, and also because of the dialect peculiarities of each village, which teachers were eager to see represented in it. One of these discussions was about the spelling of the word for "moon" in Kaingáng: "kysã", in the official orthography.

At that meeting, stating that "there are two pronunciations" for the word "kysã", one of teachers tried the following explanation: "We, who have

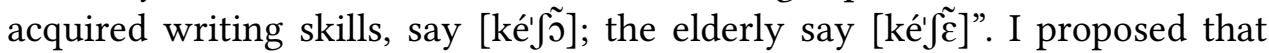
all the teachers discussed that explanation. Right after that, however, teacher

4 At that time, my idea was that female sex is marked, in Kaingang, by the particle "fi". Thus, one can distinguish "ox" and "cow": monh (= ['mbojłn]) and monh-fi (=['mbojc'fi]), respectively. I will go back to that matter within this text.

5 Cf. Wiesemann (1971:63). In Kaingáng orthography proposed by Wiesemann and imposed to native speakers, [ $\tilde{\jmath}]$ is written "ã". 
Sebastião Luiz Camargo stated: "My grandma says [ké' $\left.\int \tilde{\varepsilon}\right]$ when the moon is small and [kéfð̃] when it is big."

When I finally decided to explore the subject, and went back to my research field notes since the beginning of the 80's, I found, among others, the following distinction pointed out by João Alfredo Fortes Ndorẽ (from Nonoai, RS):

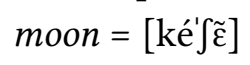

moon (when about to be full) $=\left[\text { ké' }{ }^{\prime}\right]^{\prime \prime}$

The information from the Nonoai speaker, at that time a man in his sixties, confirmed the observation of the Kaingáng teacher from Inhacorá regarding his grandmother's speech. From this initial inspiration, I decided to explore the subject.

\section{According to Wiesemann}

In Wiesemann's work (undoubtedly the linguist who studied longer and more deeply, and published more on the Kaingáng language, ${ }^{8}$ ) there are two direct references to this variation. The first, from a didactic work from the middle 60's, and the second from her PhD Thesis, published in the beginning of the 70's:

1) The $(\tilde{\varepsilon})$ and ( $\tilde{a})$ are pronounced more open than in Portuguese. In

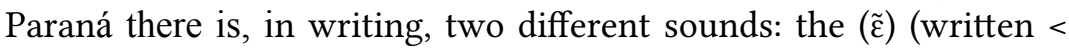

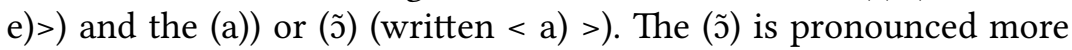
open than in Portuguese (bom). In the Southern dialect there is

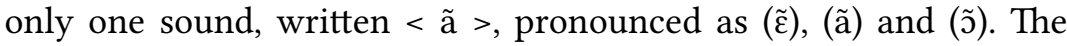
pronunciation varies with the environment: beside anterior vowels (i, e, $\varepsilon, \tilde{i})$ it is usually pronounced $(\tilde{\varepsilon})$; beside middle vowels (y, ə, a ə))) it is usually pronounced (ã), and beside back vowels (u, o, O, ũ)

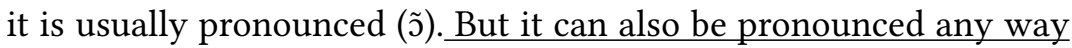

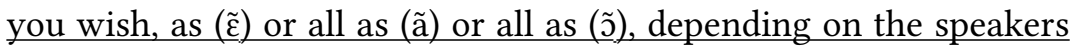
inclination. Beside the consonant $/ \mathrm{nh} /$ it is usually pronounced as (̃) (Wiesemann 1967:2).

2) In the Southern dialect ${ }^{9}$ there is only one nasalized low vowel /ã/

6 Meeting of Kaingang Teachers for School's Planning and Studies, in the "Marechal Rondon Indian School”, Inhacorá Indian Land (RS), 24/03/1999. Notes from my field notebook.

7 Kaingang Language - Toldo Chimbangue, SC. Notebook n. 2, p. 91, data 623 and 624 of 02/27/1987 (tape 9-A).

8 The Bibliografia Kaingang (Kaingáng Bibliography), lists 24 of Wiesemann's works, among which, at least a dozen original linguistic studies (cf. Noelli et al. 1998:134-137).

9 In her thesis, Wiesemann refers to 3 dialects: Paraná, Southern and São Paulo (and Xokleng as a fourth dialect). In other studies (cf. Wiesemann 1977), she refers to five: São Paulo, Paraná, Central, Southwestern and Southeastern. 
whose allophonic region takes up the vowel/İ)/ of the Paraná dialect. This vowel comes often in speech, so in the Southern dialect there is even more homophony than in the Paraná dialect (Wiesemann 1972:40). ${ }^{10}$

Wiesemann assumes the phonological analyses of Kindell, which she presents in appendix in her thesis. Concerning teh matter under consideration, Kindell's study (1972:204-205) - taken here as an "indirect reference" of the Wiesemann's own interpretation - says:

The nasalized vowel phonemes / $/$ /, /ã/ and /õ/ have freely fluctuating allophones. /z̃/ varies from a voiced nasalized mid close central unrounded vocoid [̃̃] to a voiced nasalized mid open central

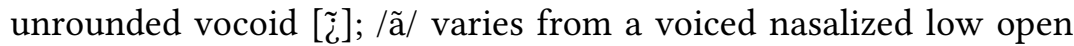
central unrounded vocoid [ã] to a voiced nasalized low close back

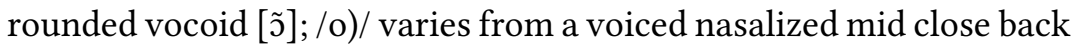
rounded vocoid [õ] to a voiced nasalized high close back rounded vocoid [ũ].

As we can see, these explanations are taking the short-cut of "free variation" (governed by the speaker's inclination) ${ }^{11}$, where very important sociolinguistic questions are hidden or left apart. However, the speaker's intuition shows that it is not a negligible matter, it is quite on the contrary a phenomenon apparently regulated by some kind of semantic notion.

\section{According to Guérios}

Mansur Guérios was one of the important Brazilian linguists of the early $20^{\text {th }}$ century interested in Indian languages. Guérios stsudied the Kaingang language, despite the short time of direct contact he had with native speakers. He came close to realizing the facts delat with here, although he did not distinguish typical cases of minimal pairs (lexical forms distinct by the difference on the use of one of the phonemes in the chain) from the true vocalic alternations in one particular lexical item. Here is a summary of what he wrote about the dialects of Tibagi (based on data from Val Floriana) and of Palmas (data from Guérios himself) ${ }^{12}$, in the 40's:

10 The translations of this and the following quotes, from texts published in any other language, are of my entire responsibility.

11 Wanda Hanke, a German researcher who visited the Kaingáng in Tibagi, PR (see following note) in the 40 's, also interpreted the alternations as mere variation: "La pronunciación no es uniforme. Una vez se oye kragn, otra vez krêgn, un tercero dice krygn." ("The pronunciation is not uniform. Once you hear kragn, another krêgn and a third one will say krygn") (Hanke 1950:77).

12 Tibagi river leaves Central-East Paraná towards North, flowing into Paranapanema. Its banks, in the lower and medium portions are traditional Kaingang territory. The Kaingangs 
Symbolic Alternations: It seems that in Kaingang we can verify (...) the most curious phenomenon of true variation, i.e., one difference of notion between two or more co-existing, synchronic words which are related, produced by any phonetic difference, but that sometimes also allies difference in form (...)

This is revealed by the following examples of Tibagiano: (...) gan, "break"b: gon, the same; xamb, "take" : xemb, the same; ran, "to enter" : ren, "run, jump"; van, "put" : ven, the same; vá-vá, "dilate" : $v e$, "stretch"; ha, "yes" : he, the same; kan, "all" : ken, the same; kara, "to enter" : kéra, the same; kara, "after" : kére, the same; fan, "break" : fen, the same; gan, "drop" : gen, "rob from someone using physical strength"; ga, "scream" : ge, "fight"; gap, "break" : gop, the same; na, "lay down": $n i$, "sit down"; $h a$, "good" : hö, the same; min, "people" : men, "animal"; ta, "in' : te, "in" : tö, "in" : ka, "in" : ki, "in" : ko, "in" : ku, "in". In Palmense: hóg-hóg, "dog" : hôig-hôig, "wild dog"; káfei, "flower" : kaáfei, "leaf”; kaikó, kaiká, kaiké, "sky" : kaikié, "cloud"; ttâin, "palm" : tãin, "palmtree"; nhantkã, "door" : nhótkó, the same; tarai, "soft": tanâin, "tender"; kaikó, "cousin": ke(n)-kê, "brother" (Guérios 1942:151).

In these examples, cases of minimal pairs are distinguished (enter $\mathrm{x}$ jump, flower $\mathrm{x}$ leaf); there are cases in which the shift in meaning is small, almost indicating derivation or direct correlation between terms ( $d o g$ and wild dog, dilate and stretch, soft and tender), and still cases in which the same term has distinct phonetic records which Guérios could not explain.

Some paragraphs afterwards, Guérios adds a comment: "It is very likely that, in many cases, this is just about phoneme variation, ${ }^{13}$ with no change in meaning. Comparing in Palmense: ixág, ixóg, "me"; katín, kétin, "come"; hamí, hemi, "bread"; etc." (1942:152). It is curious, however, that in this last part, where he surrenders to "variation" without meaning, Guérios presents terms in which the vocalic alternation seems to have distinctive role.

\section{Classifiers and Classifying Languages}

It is not possible to review here the extensive linguistic literature concerning classifiers and gender. However, we can take into consideration some suggestions of other researchers.

of Tibagi and the related groups of the centre of Paraná share the same Kaingang dialect. The Kaingang of Palmas, along the border of Paraná-Santa Catarina, share with the ones in Xapecó (in the West of Santa Catarina's Brazilian state) the same dialect.

13 The meanings of "phoneme" and "phonology" in Guérios are pre-Prague Structuralism and should not be mistaken with their current meanings. In the referred excerpt, we should read: "phonetic variation". 
Allan (1997:285) defines classifiers by two criteria:

(a) they occur as morphemes in surface structures under specifiable conditions; (b) they have meaning, in the sense that a classifier denotes some salient perceived or imputed characteristic of the entity to which an associated noun refers (or may refer). ${ }^{14}$

The same author points out three ways of "deciding whether or not classifiers have meaning" namely: (i) "using a native-speaker intuition" (ii) "using a foreigner observer intuition about the composition of nominal classes revealed by classifiers" (iii) "introducing new words or objects to a group of native speakers and see what classifiers they use with them". For him "any of these methods will reveal, for the most part, classifiers do have meaning (...) The strongest evidence of semantic classification is the ability of native speakers to classify, easy and consistently, new objects based on the observed characteristics (...)." (Allan 1997:290).

According to Allan,

the relationship between noun and classifier in classifier languages is typically explicable, but not always predictable without extensive knowledge of the relevant language. However it is not unusual for a noun class to include a number of members which SEEM to have been arbitrarily assigned to it, although a rational explanation might turn out to be available in the industrious scholar" (Allan 1997:294).

In fact, his conclusion about it, is that "there can be no doubt that classifiers reflect perceptual groupings" or, in other words "classifiers are linguistic correlates to perception" (Allan 1977:307-308).

Having compared more than 50 classifier languages, the author recognized, among them, seven categories of classification: "(i) material, (ii) shape, (iii) consistence, (iv) size, (v) location, (vi) arrangement and (vii) quanta." (Allan 1997:297). A strong statement by Allan is that "the first five happen only in classifier languages" (1997:297). That leads us to believe that, in Kaingang, what we have is a classifier related to "form". Moreover, it is interesting to observe a partial likeness with what can be seen in Navaho language (USA). In the words of Benjamin Whorf:

In Navaho (...) some terms belong to the round (or roundish) class, others to the long-object class, others fall into classes not dependent on shape. (...) I doubt that such distinctions, at least in Navaho, are simply linguistic recognitions of nonlinguistic, objective differences

14 Because of the (b) criteria, the same author suggests that "In general, European Gender is semantically empty, and the gender morphemes of European languages are not classifiers in the sense of this paper" (Allan 1977:291). 
that would be the same for all observers (...); they seem rather to be covert grammatical categories. Thus one must learn as a part of learning Navaho that 'sorrow' belongs in the 'round' class. (Whorf [1945] 1956a:91). ${ }^{15}$

About Whorf's reservation against a direct "mapping" of semantics in grammar, it is worth confronting Aronoff's observation - dealing precisely with "gender and class of nominal flexion" - that "in spite of the fact that we tend to think the morphosyntactic properties as reflex, or at least, descent from semantic categories such as sex and animability", he hasn't found "any example (historically or synchronically) of morphosyntactic properties completely unmotivated" (Aronoff 1994:62).

If many of the observations above suggest that we should take Kaingang as a classifier language, other delimitations seem to contradict facts of this language. Dixon (1986:105) proposes to differentiate classes from nominal classifiers. For him, "the grammar category of nominal class (including most of the gender systems) and the lexical-syntactic phenomenon of nominal classification (including numeral classifiers)" are distinct.

As he proposes to distinguish,

noun classes constitute an obligatory grammatical system, where each noun chooses one from a small number of possibilities. Ways of marking noun classes include a prefix to the noun(and usually also to other constituents in the noun phrase, or in the sentence, that show concord with it), as in Bantu languages; an obligatory article, as in French and German; or an inflectional suffix that shows a portmanteau of case and noun class, as in Latim.

Noun classifiers are always separate lexemes which may be included with a noun in certain syntactic environments (...) (Dixon 1986:105) ${ }^{16}$

However, from the facts so far mentioned for Kaingang, what can be observed is a morphophonological alternation similar to flexion, whichdoes not correspondent exactly to one of the realization forms of nominal classes, according to Dixon, nor to a classifying lexeme in the way he proposes.

Dixon (1986:106-7) suggests three distinctive criteria between classes of names and classifiers, that can be summarized as follows: (i) SIZE: nominal classes imply the grouping of all names of a language in a limited number

15 Quoting Hoijer (1945), Kiyomi informs that Navaho classifiers include one only class for "animability" (for living things), and three classifiers of "shape": round objects, long objects and rope-like objects. The difference between 'round' and 'rope-like' objects is that the first means 'hardness' and the last, 'flexibility'.(Kiyomi 1992:27).

16 Mariane Mithun (1986:388) is equally categorical as to classifiers: "All classificatory roots start their existence as nouns". 
of classes (usually 2 to 20), while the number of classifiers is usually much higher; (ii) REALIZATION: nominal classes always constitute a closed grammar system - as number, case and time - in which any member can be specified as a complement of the other members of the system ${ }^{17}$, so that these grammar information can be merged into one only morpheme; on the other hand, classifiers are always free forms; (iii) SCOPE: the marking of nominal class implies the existence of a grammar agreement system (with other terms) while for classifiers there is never a reference to them out of the noun phrase in which they co-occur with the specified name (or where, sometimes, occur instead of the name specified).

What some authors have said about gender can be considered before we look more closely into the examples of the Indian language in question.

\section{Gender}

First of all, yet well known, we must bear in mind the idea that grammatical gender, does not necessarily have relation to "natural gender" or sex. Not only to the fact that "female" and "male" in grammar may not correspond to female and male in sex, but also because "gender" is not a category that refers only to "female" and "male". Quoting Aronoff (1994:66):

The special property of genders as grammatical kinds of substantives is that they are distinguished from one another with respect to agreement and not that they are sex-based. Webster's third makes the second point explicit by including shape and animacy along with sex as examples of the kinds of "distinguishable characteristics" that may serve as the basis of gender.

Therefore we can find languages in which gender are animate $\mathrm{x}$ inanimate, or female $\mathrm{x}$ male $\mathrm{x}$ neutral, and it is also possible to find round $\mathrm{x}$ long, and so on.

For Corbett (1991:4), "the determining criterion for gender is agreement; this is the way in which genders are reflected in the behavior of associated words in Hockett's definition". Then, Corbett discards the treatment of the classifiers in his classic Gender, "because they do not show agreement"(Corbett 1991:5).

However the same author recognizes the necessity to define "agreement". And according to him, many researchers include the control of anaphoric pronouns by their antecedent (the girl...she) as part of the agreement. One consequence of accepting that is that languages in which pronouns are the only evidence of gender, should be recognized as having a gender system.

17 The example given is Latin in which "non-male or neutral" must be "female". In Kaingang we know that everything which is "non-female" is part of the other class (precisely nonfemale class). 
Corbett accepts this approach, which he recognizes is not unanimous, but because of that he calls those languages "pronominal gender systems" (cf. Corbett 1991:5).

Following Corbett (1991), Aronoff defines two criteria to recognize gender in any given language:

A language will have gender if and only if we find in that language (1) some form of agreement with nouns that (2) involves a distinction among noun classes, no matter what the semantic basis of the distinction may be. Indeed, since agreement and gender are syntactic phenomena, the question of the nature of the substantive basis of a gender is in principle irrelevant to our present concerns which are syntactic and morphological. (Aronoff 1994:66).

As to the way the speakers attribute gender to words they know or to new words to which they may be exposed, Corbett refuses the idea that the speaker of a language must memorize the classification of thousands of names, instead he defends gender assignment:

may depend on two basic types of information about the noun: its meaning (semantics) and its form. Information about form may in turn be of two types: word-structure, comprising derivation and inflection (morphology), and sound-structure (phonology). (Corbett 1991:7-8).

Postponing the discussion about the agreement criterion, we realize that forms of attribution of gender ranked by the author make possible to consider the facts of Kaingang discussed here as a case of gender: the speaker would refer to semantic criteria (form of the object) and phonological criteria (the referred vocalic rotation). Based on those possible determiners of gender of the words, Corbett recognizes four types of systems:

Gender Assignment I: Semantic Systems

1. Strict Semantic Systems

2. Predominantly Semantic Systems

Gender Assignment II: Formal Systems

3. Morphological Systems

4. Phonological Systems

Those of type I.1 "are systems in which the meaning of a noun determines its gender and in which, equally given the gender of a noun, we can infer something about its meaning" (Corbett 1991:8). Those of type 1.2 are the ones with semantic rules for gender assignment but allow a certain number of exceptions which cannot be taken as merely sporadic. This "semantic residue" comprises nouns whose gender is not marked according to a positive semantic 
criterion. The morphologic systems of type II.3 "are related to semantic systems", first because "they always have a semantic core" because there is no "purely morphological" systems: "the morphological rules assign the nouns in the semantic residue to gender, that is, they are required where semantic rules fail". Secondly, because "they may also overlap with the semantic rules" (Corbett 1991:34). Finally, in type II.4, a single phonological element (a feature, for example) plays the role morphemes have in type II.3. According to the author:

if, in order to establish the gender of a noun we need to refer to more than one form - whether to different inflectional forms as in the case of Russian or to the noun and the elements from which it is derived in the German examples just discussed -, then we are dealing with morphological assignment rule. If, on the other hand, gender can be established by a reference to a single form, then, we are dealing with a phonological rule (Corbett 1991:51).

This last case - as much as I.1 - is interesting when we consider Kaingang. Examples from Corbett show the use of accent position in Qafar (Ethiopia and Djibouti) to distinguish 'male' and 'female'; the quality of final vowel of the word, in Hausa (Nigeria and Niger) to similar aim; a distinction between three vowels $(\varepsilon, \mathrm{O}, \mho)$ in Godie (Liberia and Ivory) to classify "big animals", "small animals" and "liquid/natural elements"; etc.

\section{A Little More About Kaingang}

As we have seen, with the alteration of the anteriority/posteriority feature of the low nasal vowel, native speakers of Kaingang in Inhacorá, Nonoai and Xapecó linguistically reflect or attribute a distinction of form of objects referred in the world:

$$
\begin{aligned}
\text { ké }^{\prime} \tilde{\tilde{\varepsilon}} & =\text { moon } \\
\text { ké }^{\prime} \int \tilde{\partial} & =\text { full } \text { moon }^{18}
\end{aligned}
$$

Other distinctions with the same resource have been recorded. In Inhacorá, just as it happened when we were developing teaching materials, in 1999, the Kaingáng teachers discriminated between $\tilde{n \varepsilon} n$ and $\tilde{n} n$, to mean different kinds of grass:

$$
\begin{aligned}
\tilde{n} \tilde{n} & =\text { copse (thin wood) } \\
\text { nõn } & =\text { forest (thick, compact wood) })^{19}
\end{aligned}
$$

18 According to the Kaingáng, the moon is kanhru and the sun is kamẽ (cf. Veiga 2000:78). 19 In Xapecó (SC), the distinction is made between two terms: $n \tilde{\varepsilon} n$ and wõp. 
In my notes of the research carried out with Kaingang João Ndorẽ, I have also found alternation in the use of an adjective:

$$
\begin{aligned}
& \mathrm{k} \tilde{\varepsilon}^{\prime} \mathrm{fi}=\text { small, tiny (in "small stars") } \\
& \mathrm{k}^{\prime} \text { 'fi }=\text { small, tiny (in "small basket") }
\end{aligned}
$$

Wiesemann, in her dictionary (1971:43) does not bring the form of this term with $[\tilde{\varepsilon}]$ but presents "k̃̃fir" (orthographically: kãsir) with the translation: "small, tiny pl". The data from João Ndorẽ, however, point to a different direction: either the form with $[\tilde{\varepsilon}]$ is used as "plural" (at least in some dialect) as opposed to the form using [ [̃], or - as I believe to be more likely - the form

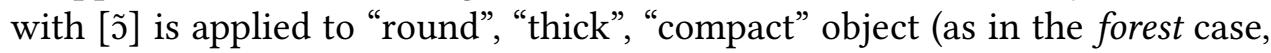
above), while $[\varepsilon]$ is used for "long" objects, and by extension: "diffuse", "not thick", "fine" (in the case of stars).

In Xapecó, I have found a semantic distinction with the same linguistic resource, which leads me to a similar interpretation, but applied to a verb. I questioned Kaingang Salvador Kẽnhkra about the reason for the use of the form $t \tilde{\varepsilon} n$ to the verb "to kill", while on another occasion I had heard from him the form tõn. The answer was, verbatim: "Use [note: tẽn] when it is a lot of small animals; when it is only one, use tõn" "20 The native speaker - as did Wiesemann referring to "plural" - tries to translate it into what it seems to be, in his opinion, the closest category in Portuguese grammar. ${ }^{21}$ Now, in the light of what has been said, I believed to be adequate to interpret his explanation as follows:

$$
\begin{aligned}
& \text { tz̃n }=\text { to kill (diffuse, spread out animals) })^{22} \\
& \text { tõn = to kill (compact, thick, round animal) }
\end{aligned}
$$

On table A below, I present some words for which I have records in both forms, with an $[\tilde{\varepsilon}]$ an $[\tilde{\jmath}]$.

20 Salvador Capanema Kẽnhkra, 03/31/1993 and 04/06/1993 - tape 2-A. Notebook Kaingáng Language, p.19v, n. 493.

21 Salvador is literate in Portuguese and reads with some fluency.

22 In the datum used as example, another clarifying semantic aspect can be observed: the "rats" hunted by the Kaingáng were not caught in units. Neither were they hunted by a man alone. They used to organize a group, then put traps set, and at night, many animals were caught (cf. Joaquim 2008:36-40: Ẽgminko). After that, they organized a great feast together. On the other hand, to kill a tapir or a deer was always a single animal hunt. 
Table $\mathrm{A}^{23}$

\begin{tabular}{|c|c|c|c|}
\hline Portuguese/English & $\begin{array}{c}\text { Kaingang } \\
\text { "long" }\end{array}$ & $\begin{array}{c}\text { Kaingang } \\
\text { "round" }\end{array}$ & Observations \\
\hline 1. cesto/basket & $\mathrm{k} \tilde{\varepsilon} \mathrm{j}$ & kõj & same speaker \\
\hline 2. coqueiro, butiá/coconut tree ${ }^{24}$ & $\mathrm{t} \tilde{\varepsilon} \mathrm{n}$ & tõn & same speaker \\
\hline 3. descendência, filhote/descent suckling & $\mathrm{kr} \tilde{\varepsilon}$ & krõ & same speaker \\
\hline 4.milho/ corn & 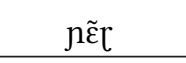 & ฤ & same speaker \\
\hline 5. pé/foot & $\mathrm{p} \tilde{\varepsilon} \mathrm{n}$ & põn & same speaker \\
\hline 6. pena/feather & fथ̃ $ᄃ$ & fว̃ & same speaker \\
\hline 7. sogro/father-in-law & ka'krẽ & ka'krõ & same speaker \\
\hline 8. tatu/armadillo & 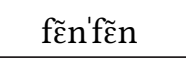 & fõn'fõn & same speaker \\
\hline 9. veado/deer & $\mathrm{k} \tilde{\varepsilon}$ 'mbe & kว̃'mbe & same speaker \\
\hline 10. debulhar milho/threshing corn & nге̃ & ฤгว̃̄ & same speaker ${ }^{25}$ \\
\hline 11. vir/to come & kẽn'tip & kõn'tĩn & same speaker \\
\hline 12. plantar/to plant & $\mathrm{kr} \tilde{\varepsilon} \mathrm{n}$ & krõn & different speakers \\
\hline 13. maracanã $X$ arara & 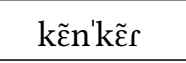 & kว̃n'kว̃؟ & different speakers \\
\hline
\end{tabular}

Restrict as the list may be - or exactly because of that - we can notice that there is no universal, unrestricted use of categorization possible by means of the vocalic alternation, which points to the arbitrarity of such a system, approximating it of the role of classifiers.

\section{Agreement}

Let's analyze what kind of agreement we can find in Kaingang, since this is one of the criteria suggested by other researchers for the acknowledgement of the existence of gender.

I have mentioned (in a footnote, above) that, about a decade ago, I understood that female sex is marked in Kaingang by the particle fi. Later, I changed slightly my point of view. Consider the following data ${ }^{26}$ :

23 Simplified phonetic transcription.

24 The distinction among "palmeira" ("high coconut tree") e "butiazeiro" ("butiá", "a low coconut tree") is often realized by the addition of the qualifier téj (tall/long) to the form

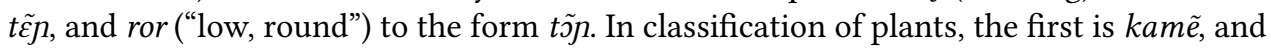
the second, kanhru.

25 Coincidence or not, in the unique datum which the native speaker had pronounced

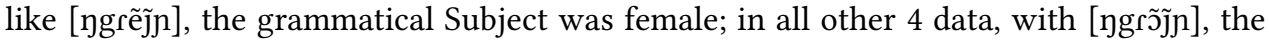
Subject was male.

26 Data 3, 4, 8 and 9 are adapted from Val Floriana (1918:540). 


\begin{tabular}{|c|c|c|c|}
\hline 1. kẽmbe ti & (a) male deer & 6. ũntẽtə fi & (a) woman \\
\hline 2. kẽmbe Pag & several male deer & 7. Iэn prũ fi & my wife \\
\hline 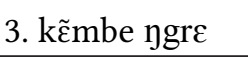 & male deer & 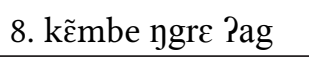 & several male deer \\
\hline 4. kẽmbe ũntẽtə & female deer & 9. kẽmbe ũntẽtə fag & several female deer \\
\hline 5. ũnๆgre & (some) man & 10. ũnygre Pag & men \\
\hline
\end{tabular}

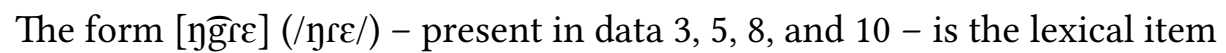
for "male sexual organ" and, by extension, "male", being the resource used to make explicit this information, whether concerning animals or human beings. In a very similar way, the form [tẽ'tə] means "female", and is used to explain the female sex, whether concerning animals or human beings ${ }^{27}$. Therefore, in 1 and 2, the information of male sex is deduced from the grammar form that indicates gender and number: $t i=[\mathrm{ti}]$, for male singular, Pag $=[\mathrm{lagy}$ ' $]$ for male plural. The female form correspondent for grammatical gender are $f i=$ [fi], and $f a y=\left[f a \widehat{g n}^{\prime}\right]$, which can be seen on data $6,7,9$. That is so correct that in 6, 8, 9 and 10 the lexical items that indicate natural sex co-occur with the grammatical marks of male and female, singular and plural.

Observe now, data 5 and 7. We can see that, in 7, the indication of female gender seems redundant or dispensable, since the term 'wife' refers to female sex. ${ }^{28}$ It shows the autonomy of the grammatical gender, and we realize this grammatical mark is also related to number. On the other hand, while in Kaingang the female form seems to be compulsorily marked, the male form (better said, all non-female forms ${ }^{29}$ is just optional. In fact, the male form is always necessary when the number needs to be clarified, and is compulsory for plural number. ${ }^{30}$

As stated above, the presence of grammatical mark can dispense the explicit reference to sex because one implies the other. The same happens in Portuguese. It is unlikely to find a situation in which someone says: $a$ jornalista fêmea ("the female journalist") or o meu companheiro macho ("my male companion"). The presence of a determiner (-a/-o) and the name flexion (companheir-o) is enough to identify the referent and its sex. So, Kaingang would not say things as in prũ têtə fi, but would probably use grammatical

27 There is a small difference with the masculine, because the word for "female sexual organ" is a different one.

28 That goes for any other similar terms, such as "mother" or "mother-in-law", etc.

29 Forms like kur ti (clothes+3rd person sg. non-fem) and ỹ̃ ti (corn+3rd person sg. nonfem) are frequent.

30 However, when there is an explicit numeral, number agreement doesn't seem to

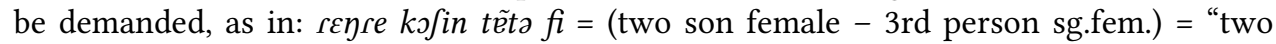
daughters" (adapted from Val Floriana 1920:169). 
gender to clarify expressions like in rengre ti ("my male partner") and in rengre $f i$ ("my female partner"). The role of $t i$, fi, ?ay and fay as numerals seems rather evident, relating the grammatical gender "female x non-female" to a clear case of syntactic Agreement.

On the other hand, the pronominal character of elements $t i, f i$, ?ay and $f a \eta$ is easily recognizable. We would also have, then, a case of "pronominal gender", from the orientation of Corbett (1991). The pronominal agreement of distance is easily found and as common as, or even more common than, the anaphoric use, which is its use in cataphora (considering languages generically, independently of its own form of syntactic construction). ${ }^{31}$ Observe these examples (in phonological form):
a) pĩ winwir ${ }^{32} \quad$ fi
ton, ifn
rengre fi
wood went pick $3^{\text {rd }}$ pers.sg.fem Nom. $1^{\text {st }}$ pers.sg. partner $3^{\text {rd }}$.per.sg.fem.
She went picking wood, my female partner

b) $\mathbf{t}$

$\begin{array}{llccc}\text { ti } & \text { tan } & \text { ter, } & \text { mĩn } & \text { ti } \\ 3^{\text {rd }} \text { pers.sg.non-fem. } & \text { Nom. } & \text { die } & \text { tiger } & 3^{\text {rd }} \text { pers.sg.non-fem. }\end{array}$

He died, the tiger ${ }^{33}$

In any of the cases discussed above, there are rules demanding agreement. Compare with Portuguese (with a difference, that in this language, the morpheme for the female gender is suffixed to the word): there is a difference in rules when one says, in this language: bela ponte ("beautiful bridge") or bela jornalista ("beautiful journalist"). In the first case, the attribution of gender in the adjective is merely syntactic (there is no semantic information, no conceptual element at stake). In the second case, the attribution of gender is both semantic (related to sex) and syntactic. Moreover, if someone is looking at a woman, and just says (speaking Portuguese): linda ("beautiful"), there are both syntactic and semantic demands at stake on this speech. Semantic because $\{-\mathrm{a}\}$, in that word, refers to or indicates a referent of the female sex in the real world; syntactic because the organization of the language demands

31 The parentheses are to warn for the inconvenient use of terms forged under the perspective of one language to describe others. Anaphora (and Cataphora) can be thought exclusively from the point of view of "time precedence", that is, the time linearity of the emission of the statement. However, from a point of view of syntactic organization, it would be possible to think of anaphora (and cataphora) working inversely in the case of languages organized with the head to the right, not to the left. In other words: "antecedent" and following can be taken as time meaning or structural meaning.

32 win = "carrying something long" + wis = "went" (sg.).

33 The Kaingangs usually translate mĩ by "tigre" (that is, tiger), rather than by "onça" (ie, jaguar). Perhaps because in Portuguese the last word is marked as female, while in Kaingang mĩ is unmarked (used with ti). 
that an adjective expresses one of the genders, by rule, since it is not inherent. Aronoff (1994:71) brings up the same issue, dealing with Spanish:

Gender is a syntactic category that is either specified lexically for a lexeme or assigned by rule. For nouns, so far as we have seen, gender is specified lexically. In the case of gender in adjectives, it is distributed syntactically by agreement. Some nouns most likely acquire their gender by rule, though not by syntactic rule. For example, there is arguably a conceptual rule that assigns Masculine and Feminine to words for biologically male and female referents that are not prespecified for gender.

Besides the case above, thatrefers to gender and agreement, there is a second situation related to the categorization of "tall/long $\mathrm{x}$ short/round" which does not take place through vocalic rotation, but through the use of distinct morphemes, implying a semantic restriction of co-occurrence: Kaingang selects specific verbs for objects classified as "tall/long" and an alternating form for "short/round" objects. See Table B:

\begin{tabular}{|c|c|c|}
\hline Kaingang $^{34}$ & Portuguese/English & When it is used \\
\hline $\mathrm{ma}^{35}$ & carregar / carry & round/low things \\
\hline $\mathrm{wa}^{36}$ & carregar / carry & tall/long things \\
\hline run & carregar / carry & water \\
\hline tuy & carregar / carry & things on one's back \\
\hline
\end{tabular}

With the form /ma/ go "short" and "round" objects such as pan, book, radio and stone. While /wa/ combines with "tall" and "long" objects such as hoe, sickle, pen, bow. The form / tuy / followed by things like bags (corn, beans or any seed), a child (carried on a blanket on the handle of the taquara) and wood (which is never a single object, long, but a pack). ${ }^{37}$

Consider, still, the following passage from Whorf (1956b:70):

The Navaho so-called 'round' and 'long' nouns are not marked in themselves, nor by any pronouns. They are marked only in the use of certain very important verb stems, in that a different stem is required for a 'round' or a 'long' subject or object. Many other verb stems are indifferent to the distinction.

34 Phonological forms.

35 Combines with other verbs: /ma-tĩn/ "to carry" ; /ma-kõtĩn/ "to bring".

36 Combines with other verbs: /wa-tĩn/ "to carry" ; /wa-kõtĩn/ "to bring".

37 In all these cases (children, bags, wood), it is possible for the object to take, in certain conditions, a long shape or a round shape. 


\section{Gender and Classifier in Kaingang}

From what has been exposed, I conclude that:

- The Kaingang language, from the Ge family, possesses pronominal agreement, which allows (according to the criteria proposed by Corbett, 1991) for a "pronominal gender system".

- The Kaingang language has, equally, rules of conceptual agreement (according to the proposals by Aronoff, 1990), which equally confirms its possibilities to have gender.

- The opposition female x non-female constitutes Kaingang gender.

- Based on the distinctions of "female" and "male" gender, Kaingang is close to the kind of language indicated in Corbett's (1991) classification as "strict semantic systems".

- A semantic system based on the opposition of gender coexists, however, in Kaingang (in the dialects mentioned) with a nominal classification system (cf. Aikhenvald 1994:144-151) that employs the category form (exclusive of classifying languages, according to Allan 1977)

- Vocalic alternations which attribute meaning of form to nouns with $|\tilde{\varepsilon}|$ and $|\tilde{\rho}|$ constitute a part of this classifying system.

- Classifiers which prefix to verbs, selected by a conceptual agreement with arguments of the verb, constitute another part of the classifying system "tall/long x short/round".

- Kaingang surprises by using a phonological resource for the expression of the classes "tall/long $\mathrm{x}$ short/round" in names and verbs.

As I have shown, some characteristics of gender marking in the Kaingang classificatory system detach this language fromthe prototypical classifying languages.

To explain this apparent discrepancy, I suggest a phonological origin for the classifier "tall/long x short/round" in Kaingang. As we will see, the hypothesis of phonological origin refers, ultimately, to a semantic anthropological issue. Anyway, considering the phonological origin proposed as follows, it is not too much to quote Hjelmslev, in the epigraph: "the linguistic system, yet stripped from "reason" (or by force be stripped from reason) always speaks to imagination and drives it" (Hjelmslev 1971:227). 


\section{About the origin of the classifying system in Kaingang}

My hypothesis about the phonological origin of the nominal classifiers "tall/long x short/round" in Kaingang is that:

a) The origin is dialectal and phonological.

b) As the Kaingang used to be the result, in every village, of inter-group alliances (always under the inspiring light of the prime alliance that united the Kamẽ and the Kanhru - as shown by Veiga 1994 and 2000 ), in some villages a union took place of a dialectal group with

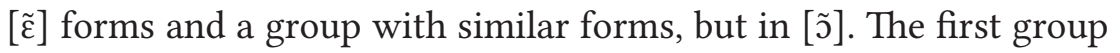
ended up identified with the long mark (attributed to Kamê), and the second one with the round mark (attributed to Kanhru).

c) In a first moment, the use of the (low and nasal) anterior or posterior vowel simply indicated the group and even the mark (ritual painting and kinship) of the enunciator. Since marriages are exogamic, in each house husband and wife had distinctive pronunciation, but a female $x$ male speech opposition never took place since there were both men and women speakers of $[\tilde{\varepsilon}]$ and men and women speakers of [ $\tilde{]}]$ in the group.

d) The following generations would decide the destiny of phonology, but the balance (real, but also desired - cf. Veiga 2000) between the exogamic moieties prevented the erasing of one of the forms (part of the collective identity, since in societies organized on clannish groups, individual and collective identity refers above all to the clan). Those alternative dialectal forms acquire meaning (semantic information), beside of the social distinction. First, the forms in $[\tilde{\varepsilon}]$ are related with marks and forms/objects referring to the "long" mark, and the alternating [ $\tilde{]}]$ with the marks and forms/objects referring to the "round" mark. In other words: for an object presented in a "long" form (state or position), when its lexical form allows it, the vowel [ $\tilde{\varepsilon}]$ is employed, expressing, in the phonological form, its physical form (e.g. [kif $\tilde{\varepsilon}]$ for the waning moon), and for the same object presented in the "round" form, the vowel [̃] is employed, expressing in the phonological form, another form of the object (e.g. [kif̃̃] for the full moon).

e) Consequences that can be verified: (i) It would be expected the use of alternative forms [ka'krẽ] and [ka'krõ], "father-in-law", spoken by a Kamẽ referring to his "Kanhru father-in-law", and by a Kanhru to his "Kamẽ father-in-law", respectively (in both cases, by a 
relation of the word to the referent) ${ }^{38}$ (ii) The alternations found in

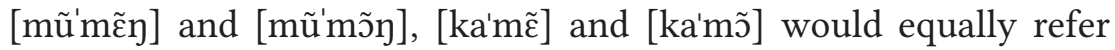
to the social (clan) classification of whom the adjective refers to? (iii) Is the distinction only possible in the words in which one of the phonemes occur $-[\tilde{\varepsilon}]$ or [ $\tilde{\jmath}]$ ? That is, would it be impossible to build the same distinction in words with other vowels, by an identical general scheme - change in the same feature - or another resource? (iv) Every word that contains one of those phonemes may or must perform the distinction? (v) The classifiers, in Kaingang, are really so restrict as suggested by the data in the present text?

As we see, this was not intended to be a conclusive work, not even an exhaustive one, on this matter, but only an approach for a research program offered to young Indian researchers to take over according to their own interests of valorization and vitalization of their language.

Translated by Odair Vedovato Jr.

\section{References}

Aikhenvald, Alexandra Y. 1994. Classe nominal e gênero nas línguas Aruak. Boletim do Museu Paraense Emílio Goeldi, Belém, v.10, n.2:137-259.

Allan, Keith. 1977. Classifiers. Language, 53, (2):258-311.

Aronoff, Mark. 1994. Morphology by itself. Stems and inflectional classes. Cambridge: MIT Press.

Corbett, Greville. 1991. Gender. Cambridge/UK: Cambridge University Press.

Dixon, Robert M. W. 1986. Noun Classes and Noun Classification in Typological Perspective. In C. Graig (ed.), Noun Classes and Categorization. Amsterdan/ Philadelphia: John Benjamins Publishing Company, p.105-112.

Guérios, Rosario F. Mansur. 1942. Estudos sobre a língua Caingangue. Notas histórico-comparativas (dialeto Palmas - dialeto de Tibagi) - Paraná. Arquivos do Museu Paranaense. Curitiba, v. II:97-177.

Hanke, Wanda. 1950. Ensayo de uma gramática del idioma Caingangue de los Caingangues de la Serra de Apucarana, Paraná-Brasil. Arquivos do Museu Paranaense, Curitiba, v.8:65-146.

38 It is difficult to predict if, in that case, the language would choose to focalize on the referent or on the enunciator. once "father-in-law" is not the quality of a person herself, but a relation of a person towards another. Only a verification test in loco will can say what the Kaingang choose. 
Hjelmslev, Louis. 1971. Animé et inanimé, personnel et non-personnel (1956). In Essais Linguistiques. Paris: Éditions de Minuit, p.220-258.

Joaquim, Dorvalino Kógjá. 2008. Kanhgág Fijén. Armadilhas Kaingang. (bilingual edition). Campinas: Ed. Curt Nimuendajú.

Kindell, Gloria. 1972. Kaingang Phonemics. In: U. Wiesemann, Die phonologische und grammatische Struktur der Kaingáng-Sprache. The Hague/Paris: Mouton, p.200-211.

Kiyomi, Setsuko. 1992. Animateness and shape in classifiers. Word, v.43, n.1:15-36.

Meillet, Antoine. 1965. Linguistique Historique et Linguistique Générale. Paris: Librairie Honoré Champion.

Mithun, Marianne. 1986. The convergence of noun classification systems. In: C. Craig (ed.), Noun Classes and Categorization. Amsterdan/Philadelphia: John Benjamins Publishing Company, p. 379-397.

Noelli, Francisco S.; SILVA, Fabíola A.; VEIGA, Juracilda; TOMMASINO, Kimye; MOTA, Luiz Tadeu; D’ANGELIS, Wilmar R. 1998. Bibliografia Kaingang. Referências sobre um povo fê do Sul do Brasil. Londrina: Ed.UEL.

Val Floriana, M. Barcatta de, Fr. 1918. Ensaio de Grammatica Kainjgang. Revista do Museu Paulista10:529-563.

Veiga, Juracilda. 1994. Organização social e cosmovisão Kaingang: uma introdução ao parentesco, casamento e nominação em uma sociedade fê meridional. Campinas: IFCH-Unicamp. Master's Thesis. Published as: Aspectos fundamentais da cultura Kaingang. Campinas: Ed. Curt Nimuendajú, 2006.

.2000. Cosmologia e práticas rituais Kaingang. Campinas: IFCH-

UNICAMP. PhD Thesis.

Whorf, Benjamin Lee. 1971a. Categorias Gramaticales. In: B.L. Whorf, Lenguaje, pensamiento y realidad. Barcelona: Barral Editores, p.105-120. [ $1^{\text {st }}$ public.:1945] .1971b. Consideración linguística del pensamiento em las comunidades primitivas. In: B.L. Whorf. Lenguaje, pensamiento y realidad. Barcelona: Barral Editores, p. 81-104.

Wiesemann, Ursula. 1967. Introdução à língua Kaingang. [Rio de Janeiro]: SIL. Mimeo.

. 1971. Dicionário Kaingang-Português, Português-Kaingang. Brasília/ Rio de Janeiro: Funai/SIL. 1972. Die Phonologische und Grammatische Struktur der Kaingang Sprache. The Hague/Paris: Mouton. 